\title{
Transformasi komunitas misi: Gereja sebagai ciptaan baru dalam Roh Kudus
}

Tony Salurante ${ }^{1}$, Dyulius Th. Bilo², David Kristanto ${ }^{3}$

1, 2Sekolah Tinggi Teologi Injili Arastamar Jakarta

${ }^{3}$ Mahasiswa Program Doktoral Free University Amsterdam

1tony.salurante@sttsetia.ac.id, ${ }^{2}$ dyuliusthomasbilo@gmail.com, ${ }^{3}$ davidkristanto.id@gmail.com

\begin{tabular}{|c|c|}
\hline & Ibstract: Transformation is the key to the growth of the church and mission. \\
\hline $\begin{array}{l}\text { Submitted: } \\
\text { October, 08, } 2020 \\
\text { Revised: } \\
\text { March, 08, } 2021 \\
\text { Accepted: } \\
\text { April, 29, } 2021\end{array}$ & $\begin{array}{l}\text { Transformation is a positive change toward Christ that marks believers' life, } \\
\text { as indicated by Paul's exhortation in Romans 12:2. The church refers to the } \\
\text { people who believe in Christ so they are renewed by the power of the Holy } \\
\text { Spirit. That transformation or renewal empowers the church to function as the } \\
\text { light of the world, as a missional community through the power of the Holy } \\
\text { Spirit. This article seeks to present the strong correlation between the spiritual }\end{array}$ \\
\hline $\begin{array}{l}\text { Keywords: } \\
\text { church; } \\
\text { missional church; } \\
\text { new creation; } \\
\text { transformation; }\end{array}$ & $\begin{array}{l}\text { transformation of the church by the power of the Holy Spirit with her function } \\
\text { as a missional community. This article elaborates the meaning of transforma- } \\
\text { tion in the New Testament, the meaning of transformation from the perspective } \\
\text { of systematic theology, and the strong correlation between spiritual trans- } \\
\text { formation and the function of the church as a missional community. }\end{array}$ \\
\hline $\begin{array}{l}\text { ciptaan baru; } \\
\text { gereja; } \\
\text { gereja misional; } \\
\text { transformasi; } \\
\text { tugas gereja }\end{array}$ & $\begin{array}{l}\text { Abstrak: Transformasi adalah kunci dari pertumbuhan gereja dan misi. Hal } \\
\text { tersebut merupakan perubahan positif yang menjadi ciri kehidupan orang } \\
\text { percaya kearah Kristus, sebagaimana nasehat Paulus dalam Kitab Roma 12:2. } \\
\text { Gereja adalah orang-orang yang percaya kepada Kristus sehingga dibaharui } \\
\text { oleh kuasa Roh Kudus. Transformasi atau pembaharuan tersebut merupakan } \\
\text { hal yang memampukan Gereja untuk berfungsi sebagai terang dunia, sebagai } \\
\text { komunitas misional oleh kuasa Roh Kudus. Artikel ini melihat relasi yang erat } \\
\text { antara transformasi Gereja oleh kuasa Roh Kudus dengan berfungsinya Gereja } \\
\text { sebagai suatu komunitas misi. Artikel ini memaparkan makna transformasi } \\
\text { spiritual di dalam Perjanjian Baru, makna transformasi spiritual dari perspektif } \\
\text { teologi sistematika, dan relasi erat antara transformasi spiritual dengan fungsi } \\
\text { Gereja sebagai suatu komunitas misi. }\end{array}$ \\
\hline
\end{tabular}

\section{Pendahuluan}

Satu konsep utama dan esensial panggilan gereja adalah transformasi. Transformasi selalu berkaitan dengan sebuah perubahan esensial dari sesuatu menuju sesuatu yang baru pada zamannya. Bersifat sentripetal dan sentrifugal, ke dalam dan keluar. Gereja sebagai komunitas ciptaan baru adalah orang-orang yang dipanggil untuk bertransformasi. Ketika seseorang percaya kepada Kristus, kehidupannya harus sepenuhnya berubah untuk kemuliaan Tuhan. Perubahan tersebut bersifat sentripetal dan sentrifugal, ke dalam dan juga ke luar, dan selalu terarah kepada kemuliaan Allah. Fase transformasi inilah yang menjadi sorotan Paulus ketika menasehati jemaat di Roma, katanya: "Karena itu, saudara-saudara, demi kemurahan Allah aku menasihatkan kamu...tetapi berubahlah oleh pembaharuan budimu, sehingga kamu dapat membedakan manakah kehendak Allah: apa yang baik, yang berkenan kepada Allah dan yang sempurna" (Rm. 12:1-2). Pembaharuan menuju kemuliaan Allah memiliki implikasi kepada misi orang-orang percaya di tengah dunia, ini adalah tujuan utama. 
Transformasi kehidupan orang-orang percaya tidak pernah berasal dari diri manusia berdosa itu sendiri, namun selalu berasal dari kuasa Roh Kudus. Satu contoh nyata atas kuasa Roh Kudus yang mengubahkan tersebut dapat ditemukan di Alkitab melalui kehidupan para rasul. Terdapat suatu perbedaan yang jelas antara kehidupan para rasul dan para murid-murid Yesus sebelum menerima pencurahan Roh Kudus dan kehidupan mereka sesudah mereka menerima pencurahan Roh Kudus. Setelah Roh Kudus dicurahkan di hari Pentakosta, orangorang percaya dipenuhi keberanian dan wibawa Ilahi untuk memuliakan Allah melalui pemberitaan Injil. Hal ini sesuai dengan apa yang dikatakan oleh Tuhan Yesus dalam Kisah Para Rasul 1:8: "Tetapi kamu akan menerima kuasa, kalau Roh Kudus turun ke atas kamu, dan kamu akan menjadi saksi-Ku di Yerusalem dan di seluruh Yudea dan Samaria dan sampai ke ujung bumi." Ayat tersebut menjelaskan bahwa kuasa yang mengubah para rasul dan para murid bukanlah berasal dari diri mereka, namun dari Roh Kudus, dan transformasi mereka oleh kuasa Allah tersebut bersifat misional, yaitu demi pemberitaan Injil Kristus sampai ke seluruh dunia.

Sekalipun Roh Kudus adalah roh yang tidak kelihatan, kehidupan yang diubahkan kuasa Roh Kudus adalah nyata dan kelihatan. Transformasi oleh kuasa Roh Kudus demi kemuliaan Allah bukanlah sesuatu yang terbatas kepada ranah privat, namun juga terpancar kepada kehidupan komunitas ciptaan baru (Gereja) dan juga kepada kehidupan bermasyarakat. Roma 12 tidak hanya merupakan suatu pertimbangan doktrinal semata, namun berimplikasi kepada pertimbangan etis. ${ }^{1}$ Melalui transformasi oleh kuasa Roh Kudus, gereja dipanggil untuk meninggalkan pemujaan diri mereka sendiri beserta dengan obsesi terhadap kekayaan, kekuasaan, kesombongan, gender dan ras agar kembali menyembah hanya kepada Tuhan sebagai Pencipta dan Tuhan mereka. ${ }^{2}$ Namun hal ini tidaklah mudah dan merupakan suatu pergumulan bagi ke-Kristen-an di setiap tempat dan waktu. Itu sebabnya transformasi Gereja atau orang-orang percaya sebagai suatu komunitas misi oleh kuasa Roh Kudus, merupakan sesuatu yang esensial di dalam pemahaman iman Kristen.

Kata metamorphoō dalam Roma 12:2 merupakan suatu perintah untuk berubah. Hal itu menunjukan bahwa ayat tersebut merupakan suatu tuntutan bagi setiap orang percaya, bukan sekedar anjuran. Tanpa Gereja mengalami transformasi oleh kuasa Roh Kudus, Gereja akan kehilangan peranannya yang vital untuk menjadi suatu komunitas misi bagi kemuliaan Allah. Di zaman postmodern, semakin banyak gereja fokus mengembangkan sarana dan fasilitas saja sehingga mengabaikan aspek transformasional dari kehidupan sosial, budaya, dan juga politik. Dever dan Stassen mengatakan: ${ }^{3}$ Perilaku ini sangat tidak etis. Secara sosiologis, hanya ada sedikit upaya dari pihak gereja dengan praktik semacam itu untuk melakukan proses akulturasi yang mentransformasikan. Secara teologis, Gereja telah gagal dalam salah satu fungsi utamanya: memuridkan. Menjadi murid lebih dari sekadar membuat pengakuan iman.

\footnotetext{
${ }^{1}$ Kate Tyler, "In, Not of: The Theological Task and the Mission of the Church," Missiology: An International Review 46, no. 4 (2018): 322.

${ }^{2}$ Paul G. Hiebert, Transforming Worldviews: An Anthropological Understanding of How People Change (Grand Rapids: Baker Academic, 2008), 307.

${ }^{3}$ John P. Dever and Glen H. Stassen, "Transformational Faith: A Concrete Discipleship Ethic for Growing Churches," Review \& Expositor 92, no. 4 (1995): 471.
} 
Gereja sedang mengalami stagnasi jika dibandingkan dengan abad-abad sebelumnya. Dalam hal ini pemimpin umat dituntut untuk memainkan peranan yang besar. Oleh sebab itu, sangatlah disayangkan jika para pemimpin Gereja memiliki waktu belajar yang tidak memadai, semangat akademis yang rendah, dan kasih persekutuan yang kering. Semua masalah ini menjadi penghambat mengapa gereja sulit mengalami transformasi, kondisi seperti ini bisa menyebakan erosi di dasar-dasar alkitabiah untuk misi dan pelayanan gereja. ${ }^{4}$ Hiebert mengingatkan Gereja, bahwa, "Biblical conversion involves real people in their real everyday lives." Tanpa transformasi Gereja oleh kuasa Roh Kudus yang berwujud nyata di dalam kehidupan sehari-hari, Gereja akan kehilangan perannya untuk menjadi suatu komunitas misi bagi kemuliaan Allah.

Dalam usaha untuk berkontribusi pemikiran tentang transformasi Gerejawi, rumusan masalah dari penelitian ini adalah sebagai berikut: "Bagaimana konsep spiritualitas transformatif dapat mempengaruhi Gereja dalam panggilannya sebagai komunitas misi?" Artikel ini berusaha untuk menunjukkan bahwa pemahaman atas makna komunitas misi yang transformasional akan memanggil Gereja sebagai komunitas orang percaya, untuk menyatakan terang Allah di bumi secara nyata.

\section{Metode Penelitian}

Pendekatan penelitian dalam artikel ini bersifat interdisipliner misiologi dan eklesiologi. Penelitian ini mengkaji berbagai data yang berasal berbagai sumber, seperti buku-buku dan jurnal-jurnal secara kualitatif, guna mendapatkan banyak pemahaman yang bisa memberi kontribusi kepada konteks saat ini. Studi kata Yunani akan dilakukan guna menafsirkan ayat Alkitab yang berkaitan dengan topik bahasan, dan konsep-konsep dalam teologi sistematika juga akan digunakan sebagai kerangka berpikir dalam melakukan pembahasan. Pertama-tama, artikel ini akan menguraikan makna metamorphoō yang terdapat di dalam kitab Roma dan kaitannya dengan tema transformasi di dalam artikel ini; kedua, artikel ini akan membahas makna konsep transformasi dari perpektif ordo salutis, dimana dalam tradisi Kristen, konsep tersebut merujuk kepada pertumbuhan rohani dari orang beriman kearah Kristus; ketiga, artikel ini akan menguraikan makna dan fungsi Gereja sebagai komunitas ciptaan baru yang berorientasi kepada misi; keempat, artikel ini akan ditutup dengan kesimpulan disertai dengan beberapa penerapan praktis.

\section{Pembahasan}

\section{Makna kata Transformasi dalam Perjanjian Baru}

Istilah "transformasi" hanya muncul empat kali saja di dalam Perjanjian Baru. ${ }^{6}$ Markus 9: 2 dan Matius 17: 2 menggunakan istilah metamorphō untuk merujuk kepada transformasi yang terjadi pada diri Yesus. Pada saat itu tubuh duniawi Yesus mengalami transfigurasi sebelum akhirnya kemulian diri-Nya muncul sedemikian rupa dalam cahaya sinar. Dalam episode ini,

\footnotetext{
${ }^{4}$ Craig Ott, The Church on Mission: A Biblical Vision for Transformation Among All People (Grand Rapids: Baker Academic, 2019), 40.

${ }^{5}$ Hiebert, Transforming Worldviews: An Anthropological Understanding of How People Change, 307; bdk. Yak. 1:22.

${ }^{6}$ Colin G. Kruse, The Pillar New Testament Commentary: Paul's Letter to the Romas, ed. Apollos (Nottingham, 2012), 464. Lihat juga Mat. 17:2; Mar. 9:2; 2 Korintus 3:18, 2 dan Rm. 12:2.
} 
Yesus meminta Petrus, Yakobus, dan Yohanes menemaninya ke puncak gunung, dimana Ia mengalami perubahan rupa (metamorfosis) dihadapan mereka (emprosthen auton). Kang dan Feldman memahami bahwa transfigurasi Yesus di sini menjadi contoh bagi para murid tentang transformasi yang terlihat dalam kehidupan seseorang. ${ }^{7}$ Frasa Metamorphoō muncul dua kali dalam Injil dan dua kali dalam surat-surat Paulus yaitu, 2 Korintus 3:18 dan Roma 12: $1-2$.

Di dalam surat Korintus, Paulus menggunakan istilah tersebut untuk menggambarkan suatu pengharapan eskatologis yang dimiliki oleh orang-orang percaya sejak pertobatan sampai kepada kemuliaan (2Kor. 3:16). Istilah ini juga muncul di dalam Roma 12:1-2. Bagian ini tidak dapat dilepaskan dari prinsip teologi yang kokoh yang dibangun oleh Rasul Paulus dari Roma 1-11. Ayat 1 dimulai dengan kata "Karena itu", frasa ini merupakan pembuka dari suatu bagian yang lebih besar, yaitu nasihat Paulus di dalam Roma 12:1-15:13.

Nasihat Paulus dalam ketiga pasal tersebut terbagi dalam dua bagian: perintah yang berkaitan dengan tingkah laku Kristen secara umum (12-13), dan pedoman untuk masalah khusus yang mempengaruhi komunitas Romawi (14:1-15:1). ${ }^{8}$ Dalam 12:2, Paulus memperingatkan orang percaya secara umum untuk tidak mengikuti pola hidup yang ada pada zaman itu (bdk. 1:28); sedangkan Roma 14:1-15:13, hampir dapat dipastikan ditujukan pada masalah khusus yang hanya ada bagi komunitas Kristen di Roma pada saat itu. ${ }^{9}$ Jelas di sini bahwa Paulus menasehati orang percaya untuk mengubah pikiran mereka untuk mengikuti suatu pola piker yang baru; dengan demikian, mereka mampu menilai apa yang benar-benar baik, sehingga memahami kehendak Tuhan (12:2). Pembaruan pikiran mereka membangkitkan pikiran ilahi (11:34), yang mana hal tersebut juga memungkinkan mereka untuk berpikir (12:3) dalam konteks yang lebih luas dari tubuh Kristus yang dikaruniai beragam (12: 4-6).

Roma 12 menjadi penghubung dari pemaparan teologis kokoh rasul Paulus dalam pasal 1:18-11:36. Nasihat etikal (imperatif) disampaikan bukan sebagai tujuan pada dirinya sendiri namun bertujuan untuk memberi bukti dari transformasi spiritual yang dialami orang percaya. Paulus telah menjelaskan hal ini dengan jelas di Pasal 6, di mana ia menunjukkan bagaimana persatuan kita dengan Kristus dalam kematian dan kebangkitan-Nya mengarahkan manusia untuk "berjalan dalam hidup yang baru" (ay. 4) dan menuntut agar kita "menampilkan diri kita kepada Allah sebagai mereka yang hidup dari antara orang mati" (ay. 13). Kekuatan Injil harus dimanifestasikan orang-orang Kristen di dalam kehidupan sehari-hari. ${ }^{10}$ Terhadap hubungan indikatif-imperatif yang kuat antara Roma 1-11 dan Roma 12-15. Landasan teologis yang kokoh mengenai kekuatan Injil yang dipaparkan dalam Roma 1-11 harus diberi wujud nyata dalam etika kehidupan sehari-hari dari orang-orang percaya yang dijelaskan di dalam Roma 12-15. Hubungan "indikatif-imperatif" dapat diungkapkan seperti ini: Allah telah melakukan sesuatu untuk kita, oleh karena itu kita harus sesuatu untuk kemuliaan Allah.

\footnotetext{
${ }^{7}$ S. Steve Kang and Michael Feldman, "Transformed by the Transfiguration: Reflections on a Biblical Understanding of Transformation and Its Implications for Christian Education," Christian Education Journal: Research on Educational Ministry 10, no. 2 (2013): 366.

${ }^{8}$ Douglas Moo, The Epistle to The Romans: TNICNT (Grand Rapids: Eerdmans, 1996), 750.

${ }^{9}$ Ibid., 746; Jika mempertimbangkan kurangnya paralel yang jelas dalam surat-surat Paulus yang lain, desakan Paulus untuk mematuhi otoritas pemerintah dalam 13:1-7 mungkin juga merupakan suatu relevansi khusus yang terbatas bagi orang-orang Kristen di Roma.

${ }^{10}$ Ibid., 744.
} 
Segala sesuatu yang terdapat dalam surat Roma berisi deklarasi dan perintah, teologi dan etika, kalimat-kalimat indikatif dan imperatif.

Hal tersebut tidak lepas dari konteks jemaat Roma pada saat itu. Jemaat Roma yang terdiri dari orang Yahudi dan bukan Yahudi memiliki berbagai isu, misalnya seperti pemisahan tempat ibadah dari sinagoge ke Gereja. ${ }^{11}$ Masalah ini tidak hanya ada di Roma tetapi juga dihadapi oleh jemaat-jemaat lain saat itu. Maka Paulus dalam pasal ini memulai dengan menjelaskan sikap etis dari orang-orang yang telah mengalami transformasi spiritual melalui nasihat dalam hal mempersembahkan tubuh (Rm. 12:1). Paulus menganalogikan konsep persembahan di zaman Perjanjian Lama, dimana domba yang diserahkan dalam keadaan hidup dan tidak bercacat. Colon mengatakan: "We might add that Paul employs the idea of a 'living sacrifice' deliberately because the sacrifice he has in mind is not martyrdom, but rather lives that are leasing to God." 12 Persembahan hidup dan pembaharuan akal budi memiliki keterikatan yang erat. Tuhan di sini menuntut gereja untuk memperbaharui pikiran orang-orang yang berbakti kepada-Nya sehingga mereka benar-benar dapat menilai hal-hal baik yang diinginkan-Nya (12:2). Perubahan yang disampaikan Paulus bukan perubahan yang bersifat abstrak, namun kepada pikiran berwujud nyata dalam tindakan sehari-hari. Itulah mengapa Roma 12-15 penuh dengan perintah-perintah yang berkaitan dengan kehidupan sehari-hari, baik dalam konteks kehidupan bergereja maupun bermasyarakat.

Frasa "berubahlah oleh pembaharuan budimu" merupakan sebuah anjuran dalam pembaruan dari dalam. Seringkali penafsir menyimpulkan transformasi hanya sekedar perubahan pikiran saja. Ini menunjukkan bahwa pikiran menjadi perhatian lebih daripada aspek kehidupan lainnya. Beberapa pandangan mengatakan bahwa metamorphoo berasal dari berbagai latar belakang yang sudah ada di zaman Perjanjian Baru. Keener menerangkan hal tersebut sebagai wawasan yang ada pada zaman Paulus saat itu. Ia menyebutkan bahwa latar belakang Helenistik untuk gagasan tentang pikiran "yang ditransformasikan," yang muncul dalam diri para filsuf yang membahas masalah-masalah tersebut. ${ }^{13}$ Dengan menyadari banyaknya gagasan tentang "pembaharuan" dalam pemikiran-pemikiran sebelumnya, Ott dengan tepat mengatakan bahwa istilah ini merupakan model kontekstualisasi yang dilakukan oleh Paulus. Ott berkata: "The biblical authors adopt this familiar religious term, but give it new meaning. This is a noteworthy example of contextualization on the New Testament whereby familiar pagan religious terminology is adopted but infused with new meaning as a bridge to understanding the Gospel."14 Paulus tidak merujuk kepada satu pemikiran baik budaya atau filsuf tertentu. Namun di sini terlihat bahwa kata kerja metamorpho yang digunakan dalam Perjanjian Baru merujuk kepada sifat, proses, dan tujuan transformasi, dan

${ }^{11}$ Kruse, The Pillar New Testament Commentary: Paul's Letter to the Romas, 460.

12 Ibid., 462.

${ }^{13}$ Craig S. Keener, The Mind of Spirit (Grand Rapids: Baker Academic, 2016), 152; Penjelasan tentang latar belakang budaya dalam konteks pelayanan Paulus dimulai dari halaman 143-172; Keener banyak menyebutkan filsuf-filsuf yang mempunyai konsep pembaharuan pikiran. Misalnya Kaum Stoa yang menyadari bahwa kebijaksanaan seseorang harus "mengubah" pikiran seseorang, menyesuaikannya dengan kebijaksanaan. Namun Paulus tidak melihat kepada sesuatu yang ada di dalam diri manusia, namun kepada Roh Kudus dan kuasa-Nya yang mentransformasi.

${ }^{14}$ Ott, The Church on Mission: A Biblical Vision for Transformation Among All People, 8. 
beberapa hubungan analogis antara transformasi dan transfigurasi Yesus Kristus. ${ }^{15}$ Dinamika pertama dari transformasi alkitabiah seperti yang disajikan dalam bagian ini adalah penyembahan pengorbanan diri. Perhatian Paulus adalah bahwa dalam totalitas keberadaan mereka, orang Kristen harus menawarkan penyembahan pengorbanan diri yang sejati kepada Tuhan. ${ }^{16}$

Lebih lanjut, konteks pasal 12 adalah persembahan tubuh sebagai persembahan yang hidup. Di sini terlihat bagaimana bahasa figuratif menolong pendengarnya untuk mengerti apa artinya kematian Kristus sebagai orang-orang percaya. Istilah transformasi, pembaharuan hidup atau metamorphosis pada ayat 2 sekaligus menjadi ekspektasi eskatologis bagi gereja yang telah ditebus, namun, masih akan melewati sebuah proses untuk menuju kemuliaan. Keener mengatakan: "Paul's choice of words regarding the reorientation of the mind is not accidental. The new mind is affected by its foretaste of the coming world in Christ. As noted

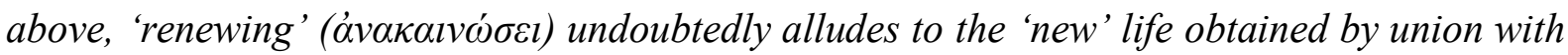

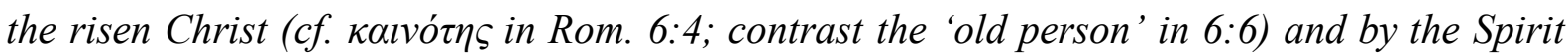

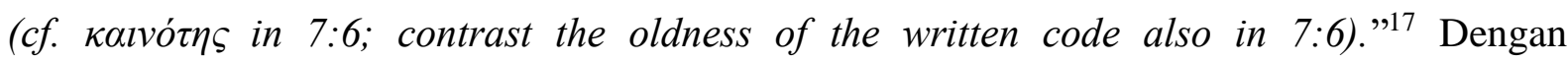
demikian, transformasi spiritual adalah pembaharuan yang dimulai dari dalam diri atas pikiran dari setiap orang yang telah ditebus Allah. Kebaruan tersebut tidak berasal dari diri manusia berdosa, namun dari kehidupan baru di dalam Kristus, dan melalui kuasa Roh Kudus; yang bertujuan agar orang-orang percaya tidak hanya tahu, namun dapat melakukan apa yang menyenangkan hati Allah, yang memuliakan Allah. ${ }^{18}$

\section{Transformasi dan Ordo Salutis}

Pada bagian berikut akan meninjau istilah transformasi dari perspektif teologi sistematika, yaitu dalam kaitannya dengan konsep ordo salutis. Di satu sisi, transformasi spiritual merupakan karya Roh Kudus yang dimulai ketika seseorang menjadi seorang percaya. ${ }^{19} \mathrm{Di}$ sisi lain, karya Roh Kudus ini juga telah bekerja di saat kita belum menjadi anak-anak Allah. ${ }^{20}$ Maka transformasi yang terjadi merupakan sebuah proses kesinambungan yang mengarah kepada tujuan Allah bagi umat-Nya. Namun demikian, hasil dari transformasi tersebut dapat menjadi indicator perbedaan antara masa lalu dan masa kini dari orang-orang percaya. Perbedaan yang dimaksud tidak hanya berdampak pada kehidupan orang beriman itu sendiri, namun juga memberi kesempatan mempengaruhi lingkungan sekitarnya. ${ }^{21}$

Makna konsep transformasi sangatlah dekat dengan konsep pengudusan dala teologi sistematika, menimbang keduanya memiliki signifikansi yang besar terhadap pertumbuhan

\footnotetext{
${ }^{15}$ Kang and Feldman, "Transformed by the Transfiguration: Reflections on a Biblical Understanding of Transformation and Its Implications for Christian Education,” 372.

${ }^{16}$ Ibid., 370.

${ }^{17}$ Keener, The Mind of Spirit, 154.

${ }^{18}$ Ott, The Church on Mission: A Biblical Vision for Transformation Among All People, 9; Kang and Feldman, "Transformed by the Transfiguration: Reflections on a Biblical Understanding of Transformation and Its Implications for Christian Education," 371.

${ }^{19}$ Hiebert, Transforming Worldviews: An Anthropological Understanding of How People Change, 307.

${ }^{20}$ Cornelis van der Kooi and Gijsbert van den Brink, Christian Dogmatics An Introduction (Grand Rapids: Eerdmans, 2017), 507.

${ }^{21}$ Stephen Ayodeji A. Fagbemi, "Transformation, Proclamation and Mission in the New Testament: Examining the Case of 1 Peter," Transformation: An International Journal of Holistic Mission Studies 27, no. 3 (2010): 219.
} 
spiritualitas dan etis orang percaya. Transformasi spiritual adalah sepenuhnya karya Allah, yang berdasarkan kepada anugerah Allah yang sepenuhnya. Dalam soteriologi, pembenaran adalah diimputasikannya kebenaran Allah kepada orang percaya, hal ini terjadi sekali untuk selamanya; sedangkan pengudusan (transformasi) diimpartasikan secara progresif seumur hidup. ${ }^{22}$ Pandangan Reformed pada umumnya sepakat kepada urutan ordo salutis yang berikut ini: Predestinasi - Panggilan - Regenerasi - Iman dan Pertobatan - Pembenaran Pengudusan / Transformasi - Pemuliaan. Akan ada banyak perbedaan dalam melihat sebuah pertobatan, namun dalam kekristenan keselamatan merupakan anugerah. Ordo Salutis dalam tradisi Reformed tidak linier, dan mengakui kuasa Allah bekerja di setiap manusia, seringkali implikasi penebusan seperti kelahiran kembali, iman, pertobatan, pembenaran dan pengudusan terjadi secara bersamaan. Dengan kata lain, menempatkan pertobatan sebelum pembenaran dalam urutan terssebut bisa berarti, dengan cara apapun, bahwa pertobatan menyebabkan pembenaran, atau merupakan syarat untuk pengampunan. Kristuslah pembenaran dan pengudusan kita (1Kor.1:30). ${ }^{23}$

Selanjutnya, anugerah keselamatan punya juga implikasi kepada natur atau keadaan obyektif antara Tuhan dan orang percaya yang secara luas disebut sebagai rekonsiliasi, tetapi perubahan subjektif dan batiniah pada orang percaya yang kita sebut transformasi. ${ }^{24}$ Seseorang yang telah percaya selama ia di dunia akan terus berhadapan dengan apa yang disebut oleh Martin Luther sebagai trinitarian kejahatan (duniawi, kedagingan dan kuasa setan). ${ }^{25}$ Kesadaran ini penting untuk tidak menyia-nyiakan anugerah yang Allah telah berikan (Gal. 5:16-26; Ibr. 12:4). Di samping itu, Wright melihat berita Injil keselamatan dunia dan ciptaan merupakan kasih karunia Allah untuk pekerjaan baik, dimana kasih karunia datang dahulu dan diterima oleh iman, yang kemudian dinyatakan keberadaannya melalui ketaatan. ${ }^{26}$ Berita Injil nyata kepada orang-orang yang mengalami transformasi yang bersumber dari Roh Kudus. Ini adalah wujud ketaatan orang percaya dari kebenaran Alkitab. Kata kuncinya adalah ketaatan sebuah sikap yang ditunjukkan dengan perubahan sesuai dengan ajaran firman Tuhan.

Dalam urutan keselamatan, ketaatan terhadap ajaran Allah menjadi ciri pertobatan yang bertransformasi. Melalui pembenaran Allah telah mengubah status hidup manusia menjadi ciptaan baru, namun perjuangan yang terus menerus tetap terjadi untuk menyadari bahwa memang kita dibenarkan dan diterima oleh Tuhan sehingga kita hidup atas dasar kedamaian batin yang ditawarkannya. ${ }^{27}$ Transformasi menjadi sebuah status krusial yang bisa memengaruhi seluruh aspek nyata sebagai orang percaya selama dibumi. Sejauh mana gereja sebagai sebuah komunitas berpikir, bertindak atau merespon tugas yang Allah tentukan. Gereja yang telah dikuduskan secara definitif perlu terus bertransformasi sehingga terjadi kekudusan yang progresif yang utamanya tetap melihat kekuatan tersebut hanya berasal dari

22 David C. Hagopian, "Sedang Menuju Kemuliaan," dalam Kembali Ke Dasar-Dasar: Menemukan Kembali Kekayaan Iman Reformed, ed. David G. Hagopian (Surabaya: Momentum, 2015), 237.

${ }^{23}$ Ibid., 240.

${ }^{24}$ Michael Bird, Evangelical Theology: A Biblical and Systematic Introduction (Grand Rapids: Zondervan, 2013), 541.

${ }^{25}$ Ibid., 542.

${ }^{26}$ Christopher J. H. Wright, Misi Umat Allah, ed. Jonathan Lunde (Jakarta: Perkantas, 2011), 250.

${ }^{27}$ Kooi and Brink, Christian Dogmatics An Introduction, 689. 
Roh Kudus. Sarumaha melihat relasi yang erat antara anugerah Allah dan kekuatan Roh dengan mengatakan, "Faktor internal sangat dibutuhkan untuk dapat menjalani proses pengudusan ini, namunpun demikian harus dikerjakan dalam penyerahan diri yang mutlak kepada Allah yang menjadi faktor external dari proses pengudusan orang-orang percaya tersebut." ${ }^{28}$ Faktor internal bukan dari manusia, tetapi adalah Roh kudus sehingga terjadilah sebuah kekudusan progresif yang menuntun gereja-Nya untuk mematikan dosa dan mempraktekkan kebenaran (Gal. 5:22-23).

\section{Tugas Gereja}

Pemaparan tentang transformasi dalam ordo salutis menunjukkan bahwa keselamatan terjadi kepada setiap individu dari orang percaya. Alkitab menjelaskan bahwa kematian Kristus bermanfaat bagi seisi dunia (Yoh. 11:25-26; 2 Kor.5:19). Mereka yang telah ditebus Kristus menjadi ciptaan baru dalam Yesus Kristus dilibatkan dalam tugas yang pernah Yesus kerjakan. Teologi Reformed secara umum membagi Gereja kepada Gereja yang kelihatan (visible) dan yang tidak kelihatan (invisible). Gereja yang tidak kelihatan terdiri dari semua orang yang sungguh percaya kepada pengorbanan Kristus dari segala tempat dan segala abad. Sedangkan Gereja yang kelihatan merujuk kepada Gereja-Gereja lokal yang dapat kita temukan saat ini. Dalam Gereja yang kelihatan tersebut, hadir juga mereka tidak terpilih, yang pada waktunya akan terhilang. Orang yang tidak terpilih tersebut ada di dalam perjanjian Allah, namun mereka bukan orang-orang yang memelihara perjanjian tersebut, namun para pelanggar perjanjian, mereka adalah ranting-ranting di dalam Pokok Anggur Kristus yang suatu hari akan dipatahkan. ${ }^{29}$

Frame menggambarkan sebuah kenyataan bahwa tidak semua orang yang masuk ke gereja adalah orang-orang taat kepada Allah. Apa yang dikatakan Frame jelas dan nyata, jika ini terjadi di gereja maka hal ini menyebabkan mengapa transformasi komunitas terjadi begitu sulit. Dengan fakta yang demikian, sulit untuk mempercayai Gereja yang tidak kelihatan, atau Gereja secara spiritual adalah sempurna dimata Allah. Namun demikian, status dan keberadaan dari Gereja yang tidak kelihatan dapat terasa, karena itulah Gereja sejati yang terdiri dari orang-orang yang suci dan dipilih Allah. Menurut Barth sebagaimana dikutip oleh Bird konsep ini berdasar pada sifat Allah yang maha kuasa dan berlimpah, di sini gereja yang tak terlihat dapat ditemukan hanya dengan mencari gereja yang terlihat. ${ }^{30}$

Banyak hal yang bisa dilakukan gereja visible, para ahli menyatakan bahwa secara mendasar terdapat 3 dasar tugas utama gereja missional: worship, nurture dan witness. Gereja yang menyembah sebagaimana Paulus jelaskan dalam Roma 12:1-2 merupakan setiap gereja yang mempersembahkan hidup, memelihara kesucian dalam setiap aspek kehidupan. Gereja yang menyembah ${ }^{31}$ meningkatkan kekuatan, karena dalam penyembahan menempatkan diri kita rendah dihadapan Tuhan, dan karena itu kita semakin mengosongkan diri kita sendiri

\footnotetext{
${ }^{28}$ Nurnilam Sarumaha, "Pengudusan Progresif Orang Percaya Menurut 1 Yohanes 1:9," Kurios: Jurnal Teologi dan Pendidikan Agama Kristen 5, no. 1 (2019): 5, http://www.sttpb.ac.id/e-journal/index.php/kurios.

${ }^{29}$ John M. Frame, Systematic Theology: An Introductioan to Christian Belief (Philipsburg: P\&R Publishing, 2013), 1019.

${ }^{30}$ Bird, Evangelical Theology: A Biblical and Systematic Introduction, 733.

${ }^{31}$ Penjelasan pada bagian ini tetap memperhatikan arti penyembahan secara individual dan komunal.
} 
dalam pujian yang tak terputus. ${ }^{32}$ Kekuatan yang berasal dari Tuhan untuk mampu menjalankan perannya sebagai orang percaya. Dengan menyembah memahami bagaimana kemuliaan Tuhan (Ibr.12:28). Tuhan yang kita sembah bukanlah subjek soliter yang begitu terpikat dengan kebesaran-Nya yang luar biasa sehingga dia menikmati pujian dari ciptaan-Nya. Namun Tuhan yang disembah adalah Allah Tritunggal yang memiliki kasih yang besar bagi seisi dunia yang telah berkorban bagi ciptaan-Nya. Ferguson membuat ini menjadi jelas:

Sikap dasar manusia di hadapan Allah adalah rasa ketergantungan dan kerendahan hati. Ini mengikuti kebenaran bahwa Allah adalah Pencipta. Semua milik manusia berasal dari Allah. Alkitab berulang kali menegaskan bahwa Allah yang Esa adalah Pencipta (Kis. 14:15; 1 Kor. 8: 6). Sebagai Pencipta dunia dan segala sesuatu di dalamnya, dia tidak membutuhkan apa-apa, bahkan penyembahan (Kis 17: 24-25). Asal mula dosa adalah keinginan manusia untuk menjadi tuhan (gen. 3: 5-6). Oleh karena itu, Alkitab memperlakukan dengan sangat serius penyembahan berhala, tidak menyembah apapun selain Allah (Ef. 5: 5 dan Kol. 3: 5). ${ }^{33}$

Roh Kudus sumber bagi kehidupan gereja, jika gereja adalah tubuh Kristus, Roh Kristus adalah sumber hidup dari sebuah tubuh. Sama seperti tubuh tanpa roh adalah mati, begitu juga tanpa Roh Kudus tidak akan ada gereja, tidak ada komunitas sama sekali. Ferguson menjelaskan bahwa mereka yang memiliki Roh menunjukkan keanggotaan dalam umat Allah, dan partisipasi dalam Roh adalah dasar dari kehidupan bersama. ${ }^{34}$ Melalui Roh Kudus, Tuhan membuka diri bagi manusia dan mengundang kita untuk hidup disekitarnya, dalam hubungan yang dekat dengan Yesus Kristus. Tujuan utama Allah membentuk Gereja adalah untuk kemuliaan Allah (Mzm. 147:1). Sebagaimana nampak penekanan dalam Yohanes 4:23-24 bahwa menyembah dalam ibadah perlu dilakukan secara spiritual dan benar, tulus dan murni. Ini yang menjadi bagian dalam konsep tranformatif gereja.

Gereja adalah Karya Allah Tritunggal, karya dari kematian Kristus yang telah menebus umat-Nya. Kasih Kristus membawa kita kembali kepada-Nya untuk senantiasa memperhatikan bagaimana gereja Kembali menghadirkan Injil dalam setiap konteksnya. Menurut Chapell Injil bukan hanya ditujukan pada penginjilan dalam kegiatan khusus namun berita tentang kasih karunia Allah bagi kehidupan Kristen sehai-hari merupakan hal yang penting seperti halnya dengan pertobatan. ${ }^{35}$ Dari perspektif tersebut maka peran esensial gereja adalah kehadiran nyata komunitas penyelamatan eskatologis di dalam Kristus. ${ }^{36}$ Secara provokatif Goheen menyatakan bahwa "The church is called to be oriented to the world." 37 Jika gereja tidak mampu menjawab masalah disetiap konteksnya maka gereja masih belum mengalami transformasi yang mengubah komunitasnya.

Di samping hal tersebut, komunitas yang tidak memahami identitas dan tugas gereja akan menghabiskan sebagian besar energinya dengan hal-hal duniawi (church oriented), yang

\footnotetext{
${ }^{32}$ Scott W. Sunquist, Understanding Christian Mission: Participation in Suffering and Glory (Grand Rapids: Baker Academic, 2013), 281.

${ }^{33}$ Everett Ferguson, The Church of Christ: A Biblical Ecclesiology for Today (Grand Rapids: Eerdmans, 1996), 229.

${ }^{34}$ Ibid., 107.

${ }^{35}$ Bryan Chapell, Christ Centered Worship: Kiranya Injil Membentuk Perbuatan Kita (Surabaya: Momentum, 2009), 143.

${ }^{36}$ Kooi and Brink, Christian Dogmatics An Introduction, 576.

${ }^{37}$ Michael W. Goheen, Introduction Christian Mission Today: Scripture, History and Issues (Downers Grove: IVP Academic, 2014), 307.
} 
tidak memiliki orientasi misi Injil dan kekekalan. Chapple mengaskan: "Kepedulian untuk melihat kuasa Allah di antara umat-Nya menuntut kita tidak meninggalkan esensi ibadah yang menyatakan kemuliaan-Nya. Jika kita tidak memahami kemuliaan-Nya, maka kita tidak akan mampu memberi-Nya pujian yang tepat serta merendahkan diri di hadapan-Nya." 38 Namun yang dimaksud memiliki orientasi kepada dunia sebagai komunitas misional adalah partisipasi gereja menurut misi keselamatan Allah yang tertuju kepada manusia dan ciptaan. Goheen mengkritik apa yang terjadi dimasa lampau dimana banyak misionaris yang melakukan tugas misi yang beroritenasi hanya kepada yang mengutus. Allah disembah karena apa yang telah Ia lakukan bagi manusia dan gereja. Salah jika orang percaya datang menyembah untuk apa yang bisa mereka peroleh dari-Nya. Kita bertindak seolah-olah Tuhan ada untuk memenuhi kebutuhan kita, padahal, kenyataannya, kita bahkan tidak tahu apa kebutuhan kita yang sebenarnya sampai Tuhan mengungkapkan diri-Nya kepada kita dan kita menemukan jati diri yang sebenarnya dalam Dia. ${ }^{39}$ Gereja menjadi pusat penyembahan, merayakan sakramen dan belajar untuk menyatakan kasih Tuhan kepada sesama dan ciptaan lain. Iman akan bertumbuh dalam berbagai hal praxis juga bukan pengetahuan teologis belaka.

Tugas kedua yang melaluinya Tuhan memanggil orang-orang percaya adalah mendidik. Istilah edifikasi dipahami sebagai sebuah tindakan yang didahului dengan sebuah pemikiran matang secara disiplin, rendah hati dan berdampak kepada orang lain. Edifikasi dalam waktu gereja berupa khotbah, memelihara ajaran atau saling mendidik. Setelah Yesus bersama muridnya melakukan Perjamuan Malam, Ia menugaskan para murid untuk mengikuti apa yang telah ia lakukan. Dalam hal ini Kristus memerintahkan kita juga untuk saling mengajar dan membangun bersama. Kekristenan bukanlah tentang kesempurnaan melainkan hal penting adalah persekutuan mutualitas. ${ }^{40}$ Yesus tidak hanya menghabiskan waktu untuk mewartakan Kerajaan Allah kepada banyak, tetapi dia juga memberikan waktu kepada para murid-murid mengajar di dalam misteri kerajaan-Nya. Yesus mengetahui kebutuhan Pendidikan akan pengajaran bagi mereka yang sudah bertobat.

Manusia tidak bisa mengetahui secara pasti siapa saja yang dipilih Allah dan diselamatkan-Nya, bahkan sekalipun ia berada di dalam Gereja. Dengan menyadari akan situasi tersebut penting untuk memikirkan apa yang disampaikan Johnson "Panggilan seseorang untuk menjadi seorang Kristen tidak datang sebelum atau sesudah seseorang dipanggil ke dalam gereja, tetapi panggilan ke dalam gereja bersamaan dengan panggilan untuk menjadi seorang Kristen." ${ }^{41}$ Semua ini adalah tugas setiap orang percaya dalam komunitas yang terus berubah dan berkembang setiap saat, ini harus menjadi bagian dari gereja karena dosa masih ada diantaranya. ${ }^{42}$ Kegiatan tersebut berkaitan dengan proses transformasi atau pembaharuan spiritual yang berimplikasi pada sikap hidup. Gereja yang sejati akan terus belajar, melatih, memelihara dan menjaga. Tujuan dari ini semua adalah untuk menjadi gereja yang benar-

\footnotetext{
${ }^{38}$ Chapell, Christ Centered Worship: Kiranya Injil Membentuk Perbuatan Kita, 144.

${ }^{39}$ Ferguson, The Church of Christ: A Biblical Ecclesiology for Today, 227.

${ }^{40}$ Stanley J. Grenz and Jay T. Smith, Created for Community: Connecting Christian Belief with Christian Living, Edisi 3. (Grand Rapids: Baker Academic, 2015), 183.

${ }^{41}$ Patrick W. T. Johnson, The Mission of Preaching: Equipping the Community for Faithful Witness (Downers Grove: IVP Academic, 2015), 74.

${ }^{42}$ Frame, Systematic Theology: An Introductioan to Christian Belief, 1039.
} 
benar memahami Injil dan mengalami Injil dalam berbagai komunitas, hidup berdasarkan kebenaran Injil. Bird mengatakan, "Discipleship is a matter of learning to live out the realities that the gospel creation. And proclaiming the gospel is the mission of the church."43

Gereja yang berhenti untuk belajar akan sulit untuk membedakan mana ajaran yang yang sehat dan tidak. Dalam bukunya The Drama of Doctrine Vanhoozer menegaskan pentingnya pengetahuan yang akan membawa gereja pada sebuah transformasi yang mempengaruhi praxis gereja di dunia. ${ }^{44}$ Ketika orang lain melihat bagaimana kehidupan orang Kristen dan bagaimana mereka saling mengasihi, dunia belajar tentang Kerajaan Allah. Di sinilah kita dapat dengan mudah melihat bahwa ibadah dan kesaksian berbaur satu sama lain. Kristus yang telah menyelamatkan manusia memanggil gereja juga untuk saling membangun sehingga terjadi transformasi spiritualitas yang dewasa (Ef. 4:11-13). Dalam kesatuan yang fundamental dari wawasan dunia atau nilai-nilai kekristenan maka transformasi itu mendorong terjadinya sebuah harmonisasi (Rm.12:16). Berbagai aktifitas seperti khotbah dan doa memiliki peran sentral didalamnya. Melalui pola ini, yaitu berkotbah menyiratkan bahwa pemberitaan misi memupuk praktik kehidupan komunal yang menunjukkan maksud Tuhan bagi kehidupan seluruh dunia. ${ }^{45}$ Melalui doa, gereja menjadi perantara satu sama lain karena bersama-sama geraja adalah "imamat." Masing-masing darinya berfungsi sebagai imam, berbagi hak istimewa untuk saling mendoakan. ${ }^{46}$ Dengan merawat serta mendidik membangun iman sebagaimana Paulus sampaikan kepada jemaat Korintus, pasal 14 menjadi perhatian penuh tentang hal ini.

Tugas ketiga, yaitu menjadi saksi Kristus (diarmartyreō, lih. Kis 8:6). Menjadi saksi Kristus dalam konteks ini mengambil bagian dalam pekerjaan Misi Tuhan dalam penginjilan (Euangelizomai, Kis. 8:4, 12, 25) dan pelayanan. Kedua hal ini tidak bisa terpisahkan, tanpa penginjilan maka pelayanan apapun menjadi tidak berarti. Sebesar apapun pelayanan yang dilakukan gereja jika tanpa penginjilan semua menjadi sia-sia. Pelayanan tanpa memikirkan penginjilan tidak memberikan dampak bagi komunitas. Komunitas misional senantiasa memikirkan kedua hal tersebut dalam masa transformasi secara bersama dan seimbang. Melalui penginjilan maka kita menyatakan proklamasi bahwa Tuhan telah campur tangan dalam sejarah untuk membawa keselamatan kita (Mrk. 1:15). Komunitas yang mengalami transformasi menyatakan bahwa Tuhan sedang bertindak menuju pemenuhan tujuan ciptaanNya, yaitu pembentukan komunitas baru. Dalam pelayanan gereja menunjukkan belas kasih yang asalnya dari Tuhan.

Di samping itu, Sunquist mengatakan dengan tegas: "Witnessing without worship is a vain human invention. Worship without witness is deception, as if we are truly honouring God while we disobey his clearest and last command." $" 47$ Sunquist melihat bersaksi dan menyembah menjadi sebuah gaya hidup yang esensial bagi gereja, untuk mencapai hal

${ }^{43}$ Bird, Evangelical Theology: A Biblical and Systematic Introduction, 705.

${ }^{44}$ Kevin J. Vanhoozer, The Drama of Doctrine: A Canonical Linguistic Approach to Christian Doctrine (Louisville: Westminster John Knox Press, n.d.), 399-420. Vanhoozer melihat peran yang besar dari gereja untuk menyatakan pertunjukan yang spektakuler dalam Sejarah keselamatan Allah yang ia pandang sebagai sebuah narasi drama yang disutradarai oleh Allah sendiri.

${ }^{45}$ Johnson, The Mission of Preaching: Equipping the Community for Faithful Witness, 124.

${ }^{46}$ Grenz and Smith, Created for Community: Connecting Christian Belief with Christian Living, 184.

${ }^{47}$ Sunquist, Understanding Christian Mission: Participation in Suffering and Glory, 283. 
tersebut Roh Kudus menuntun gereja-Nya. Saat Yesus memproklamirkan kerajaan Allah, demikian juga gereja menjadi saksi pemerintahan Allah dan memanggil orang-orang untuk bertobat mengingat Kedatangan Kristus kembali. ${ }^{48}$ Penginjilan menjadi hal penting sebagai ciri utama dari gereja, pelayanan penginjilan pada zaman modern harus kembali menjadi ciri utama dari gereja-gereja yang mengalami transformasi spiritualitas. Secara konteks, gereja akan terus berada dalam masa yang sulit karena berada pada zaman akhir.

Pandangan-pandangan yang telah dijelaskan menunjukkan bagaimana gereja merupakan komunitas dari penginjilan, sebuah perkumpulan orang-orang yang mencintai dan menghidupkan Injil. Maka Ibadah, misi, etika, simbol, kesaksian, dan spiritualitas gereja dibentuk oleh apa yang dipikirkannya dan apa yang dilakukannya dengan Injil Yesus Kristus. Injil adalah tanda dan misi dari Gereja Kristus yang otentik. ${ }^{49}$ Banyak hal yang bisa dikerjakan gereja sebagai komunitas baru disetiap konteksnya, sekalipun tidak seluruhnya sesuai dengan keinginan Allah. Akhirnya harus dikatakan bahwa transformasi merupakan proses dan bentuk akhir yang nyata bagi gereja maupun orang percaya yang nampak dalam kehidupan seharihari. Mereka mengalami proses yang tidak berhenti dalam aspek spiritualitas dan praktis sampai Kristus datang yang kedua kali.

\section{Kesimpulan}

Transformasi gereja merupakan hal signifikan dalam spiritualitas komunal sebagai ciptaan baru dalam Roh. Doktrin gereja penting untuk memiliki pandangan yang benar tentang misi gereja; dengan pemahaman yang dangkal secara teologis, atau tidak benar, tentang sifat gereja, kita pasti akan mengembangkan pandangan yang salah tentang hubungan gereja dengan dunia, yang akan menghasilkan pemahaman yang salah tentang misi. Fase transformasi merupakan bukti gereja menjalankan perannya dalam kebenaran sekaligus tanda gereja sebagai komunitas mengalami transfomasi baik dari dalam dan luarnya. Transformasi dalam komunitas iman menunjukkan otentitas kepada spiritualitas gereja yang akan terungkap dari drama penebusan Tuhan.

Selain itu, penelitian ini menunjukkan bagaimana iman dan gereja transformatif berperan signifikan di tengah dunia. Gereja transformatif selalu menghasilkan gerakan pertumbuhan otentik dalam pertobatan dan keanggotaan, dalam pemuridan yang setia, dan dalam pengaruh transformatif pada budaya sekitarnya. Transformasi spirtiualitas yang Tuhan berikan kepada umat-Nya akan terus terungkap di dalam kehidupan gereja dan di dunia bersama Roh Kudus. Penelitian ini adalah titik awal yang bisa memberi pandangan lain tentang kehadiran gereja di konteks dunia dan mendorong gereja di Indonesia untuk memahami makna perubahan hidup yang diberikan Roh Kudus. Penelitian selanjutnya diperlukan untuk melengkapi berbagai keterbatasan pembahasan penulis, dengan demikian akan mampu melengkapi pemikiran-pemikiran lain yang berguna dan berkontribusi bagi dunia teologi misi dan eklesiologi.

\footnotetext{
${ }^{48}$ Ferguson, The Church of Christ: A Biblical Ecclesiology for Today, 285.

${ }^{49}$ Bird, Evangelical Theology: A Biblical and Systematic Introduction, 707.
} 


\section{Referensi}

Bird, Michael. Evangelical Theology: A Biblical and Systematic Introduction. Grand Rapids: Zondervan, 2013.

Chapell, Bryan. Christ Centered Worship: Kiranya Injil Membentuk Perbuatan Kita. Surabaya: Momentum, 2009.

Dever, John P., and Glen H. Stassen. "Transformational Faith: A Concrete Discipleship Ethic for Growing Churches." Review \& Expositor 92, no. 4 (1995): 471-487.

Fagbemi, Stephen Ayodeji A. "Transformation, Proclamation and Mission in the New Testament: Examining the Case of 1 Peter." Transformation: An International Journal of Holistic Mission Studies 27, no. 3 (2010): 209-223.

Ferguson, Everett. The Church of Christ: A Biblical Ecclesiology for Today. Grand Rapids: Eerdmans, 1996.

Frame, John M. Systematic Theology: An Introductioan to Christian Belief. Philipsburg: P\&R Publishing, 2013.

Goheen, Michael W. Introduction Christian Mission Today: Scripture, History and Issues. Downers Grove: IVP Academic, 2014.

Grenz, Stanley J., and Jay T. Smith. Created for Community: Connecting Christian Belief with Christian Living. Edisi 3. Grand Rapids: Baker Academic, 2015.

Hagopian, David C. "Sedang Meuju Kemuliaan." In Kembali Ke Dasar-Dasar: Menemukan Kembali Kekayaan Iman Reformed, edited by David G. Hagopian. Surabaya: Momentum, 2015.

Hiebert, Paul G. Transforming Worldviews: An Anthropological Understanding of How People Change. Grand Rapids: Baker Academic, 2008.

Johnson, Patrick W. T. The Mission of Preaching: Equipping the Community for Faithful Witness. Downers Grove: IVP Academic, 2015.

Kang, S. Steve, and Michael Feldman. "Transformed by the Transfiguration: Reflections on a Biblical Understanding of Transformation and Its Implications for Christian Education." Christian Education Journal: Research on Educational Ministry 10, no. 2 (2013): 365-377.

Keener, Craig S. The Mind of Spirit. Grand Rapids: Baker Academic, 2016.

Kooi, Cornelis van der, and Gijsbert van den Brink. Christian Dogmatics An Introduction. Grand Rapids: Eerdmans, 2017.

Kruse, Colin G. The Pillar New Testament Commentary: Paul's Letter to the Romas. Edited by Apollos. Nottingham, 2012.

Moo, Douglas. The Epistle to The Romans: TNICNT. Grand Rapids: Eerdmans, 1996.

Ott, Craig. The Church on Mission: A Biblical Vision for Transformation Among All People. Grand Rapids: Baker Academic, 2019.

Sarumaha, Nurnilam. "Pengudusan Progresif Orang Percaya Menurut 1 Yohanes 1:9." Kurios: Jurnal Teologi dan Pendidikan Agama Kristen 5, no. 1 (2019): 1-11. http://www.sttpb.ac.id/e-journal/index.php/kurios.

Sunquist, Scott W. Understanding Christian Mission: Participation in Suffering and Glory. Grand Rapids: Baker Academic, 2013.

Tyler, Kate. "In, Not of: The Theological Task and the Mission of the Church." Missiology: An International Review 46, no. 4 (2018): 320-332.

Vanhoozer, Kevin J. The Drama of Doctrine: A Canonical Linguistic Approach to Christian Doctrine. Louisville: Westminster John Knox Press, n.d.

Wright, Christopher J. H. Misi Umat Allah. Edited by Jonathan Lunde. Jakarta: Perkantas, 2011. 